\title{
The Effect Of Learning Strategy And Musical Intelligence On The Students Achievement In Solfegio
}

Case Study at SMA Negeri 2 Pematangsiantar North Sumatera Indonesia

\author{
Rinaldo Abednego Simanjuntak \\ Department of Education Technology \\ Postgraduate Program \\ State University of Medan \\ Medan, Indonesia \\ Corresponding email : s.rinaldoabednego@gmail.com
}

\author{
Efendi Napitupulu \\ Department of Education Technology \\ Postgraduate Program \\ State University of Medan \\ Medan, Indonesia
}

\author{
R. Mursid \\ Department of Education Technology \\ Postgraduate Program \\ State University of Medan \\ Medan, Indonesia
}

\begin{abstract}
This study aims firstly to find out the difference of Solfegio learning achievement of students applied Quantum Learning strategy and Expository learning strategy, secondly to discover the differences of learning achievement betweenthe students with high musical intelligence and students with how have low musical intelligence, thirdly to determine the presence or absence of interaction between learning strategies and musical intelligence effects in influencing students' Solfegio learning achievement. This research was conducted at SMA Negeri 2 Pematangsiantar. The population in the study was all students of Grade XI PMIA(Science program) consisted of 251students. The sample in this study was taken by cluster random sampling. The research method was experimental method with $2 \times 2$ factorial design. The data analysis technique used was a two way analysis of variance (two way ANOVA) with significance level $\alpha=0.05$ with Bartlett test and further test using Scheffe test. The research findings showed, first the Solfegio learning achievement of the students by using Quantum Learning strategy was higher than the students' Solfegio learning achievement by using Expository learning strategy with $F_{\text {count }}>F_{t}$ able $(16.29>3.99)$.Second, the Solfegioachievement of students with high musical intelligencewere higher than the students with low musical intelligence where $F_{\text {count }}>F_{\text {table }}(10.23>3.99)$. Third, there was interaction between learning strategy and musical intelligence in influencing student solfegio learning achievement by $F_{\text {count }}>F_{\text {table }}$ $(17.47>3.99)$. Scheffe test on Solfrgio learning achievement for students' with high musical intelligence taught using Quantum Learning strategies are higher than those with high musical intelligence taught using Expository Learning strategy were verified the truth. For Scheffe's test of Solfegio learning achievement of students with high musical intelligence taught
\end{abstract}

using a Quantum Learning strategy was higher than the students with low musical intelligencetaught using Quantum Learning strategy was also verified to be true.

\section{INTRODUCTION}

Senior High School (SMA) is one of the educational institutions that provide services in natural sciences, social sciences, mathematics, sports, cultural arts, and others. Schools as a formal education institution must provide knowledge and equip students with skills to prepare competent humans. Therefore, teachers are expected to be able to form students who are skilled and have skills in various fields of science including in the field of arts and culture. Where art and cultural subjects based on the 2013 curriculum include art, dance, theater arts and music arts.

Solfegio is an exercise in hearing ability or musical acuity, both rhythmic accuracy and accuracy of tone. Solfegio aims to provide an understanding of the distance of one note to another by singing various forms of notation, by singing different tone intervals. In its development solfegio not only sings but also hears and reads tones. The ability to read tones is called the Reading Sight, the ability to hear tones is called Ear Training, while the ability to sing is called Sight Singing. 
Through initial observation, this situation may be caused by several factors. The first factor is in students themselves, most students in each class do not have initial information about the science of solfegio. This certainly will be very difficult for a student to quickly adapt to the lessons he is going to learn. The second factor is the low interest of students to take music courses outside of school lessons through non-formal education. The high cost of music courses may also be an additional reason, making students reluctant to take music courses. This also greatly influences a student's ability to take music art lessons at school. As a comparison of some students who have attended music courses outside of school, their abilities are good enough in reading beam notation, and are already good at reading song scores using one of the musical instruments. Of course it is very inversely proportional to students who have never attended a music course at all, have no initial experience, their understanding of music is very low.

The third factor is the low talent of students in music. Most students in each class do not have artistic talent, thus affecting their interest in the lesson. This can be seen in the teaching and learning process, in students there is no passion or motivation to improve learning skills solfegio. Then the teacher quality factor also determines the success of students in improving students' competencies in learning. In improving student learning outcomes is to fix learning strategies that are appropriate and relevant for the achievement of learning goals. Using improper learning strategies will result in students being bored and lazy to learn. Teaching and learning activities are less interactive and less varied, resulting in boredom in students and reduce interest in learning. This will have an impact on students' grades.

The results of the initial survey and data obtained at SMA Negeri 2 Pematangsiantar show that the expected achievement of competencies has not been maximized. The value of learning music in every class is low. This can be seen from the data of learning outcomes obtained from the Wakasek Curriculum Field of SMA Negeri 2 Pematangsiantar in the last three years since the $2013 / 2014$ school year up to the $2015 / 2016$ school year, as in the Table

TABLE 1. LEARNING OUTCOMES FOR CULTURAL ARTS

\begin{tabular}{|c|c|c|}
\hline Academic & $\begin{array}{c}\text { Lowest } \\
\text { Value }\end{array}$ & $\begin{array}{c}\text { Year Top } \\
\text { Rated }\end{array}$ \\
\hline $2013 / 2014$ & 60 & 83 \\
\hline $2014 / 2015$ & 60 & 85 \\
\hline $2015 / 2016$ & 65 & 84 \\
\hline
\end{tabular}

Based on the data in the table above obtained the results of learning art and culture for the 2014 to 2016 school year is low, the lowest is at a value of 60 , while the value of the minimum completeness criteria (KKM) value of cultural arts practices is a value of 75 . The low value of these students may be caused by learning strategies applied is a learning strategy that is only teacher-centered in the solfegio learning process is not able to maximize efforts to improve student learning outcomes. And also musical intelligence factors that tend to be low can also result in low learning outcomes of students' solfegio.

By using appropriate and appropriate learning strategies, students' learning outcomes are expected to be improved. One strategy that is predicted according to the characteristics of music art subjects is a quantum learning learning strategy from constructivism. Quantum learning strategies are translations of foreign languages, namely quantum learning. Bobbi DePorter \& Mike Hernacki, (2001: 16) state that Quantum Learning is tips, instructions, strategies and the whole learning process that can sharpen understanding and memory, and make learning a fun and useful process. Quantum learning assumes that students, if they are able to use their potential reasoning and emotions accurately, will be able to make achievements that cannot be predicted beforehand.

With the right learning method, students can achieve multiple learning achievements. One of the basic concepts of this method is that learning must be fun and take place in an atmosphere of joy, so that the entrance to new information will be wider and well recorded. Thus, quantum learning can be said as a learning strategy that emphasizes to provide meaningful benefits and also emphasizes the level of enjoyment of students or students.

With the right learning method, students can achieve multiple learning achievements. One of the basic concepts of this method is that learning must be fun and take place in an atmosphere of joy, so that the entrance to new information will be wider and well recorded. Thus, quantum learning can be said as a learning strategy that emphasizes to provide meaningful benefits and also emphasizes the level of enjoyment of students or students.

In learning solfegio musical intelligence is needed in a student. In other words, musical intelligence greatly influences the success of a student in learning solfegio. Gardner. H (1983: 9) revealed that musical intelligence is an individual's ability to compose songs and music, sing and play musical instruments, and can appreciate all types of music, as well as having a strong sensitivity to universal harmony and awareness of various patterns of life. Gardner. H (1983: 10) believes that musical intelligence is the center of human experience and is the beginning of the emergence of individual intelligence. Musical intelligence is closely related to other types of intelligence.

Likewise in learning solfegio, the musical intelligence of a student is very influential on the ability to read beam notation or learn solfegio in music art lessons. In connection with the above problems, then in this study, efforts to improve students' solfegio learning outcomes in music arts subjects were proposed by presenting a learning strategy of quantum learning from constructivism and expository learning strategies, while those relating to student characteristics involved a level of musical intelligence in students . Based on the above matters, it is necessary to do research on the Influence of Learning and Musical Intelligence Strategies on Solfegio Learning Outcomes in Class XI Students of Pematangsiantar State Senior High School 2. 


\section{METHOD}

This research was carried out in Class XI PMIA Pematangsiantar 2 State Senior High School Even Semester 2017/2018 Academic Year, both for instrument testing and experimental implementation. The population of this study were all students of Class XI PMIA of SMA Negeri 2 Pematangsiantar consisting of 7 classes with 245 students. In this study the population of 240 people from 7 classes, but in this study only took 2 classes with a total of 71 samples, sampling was done by cluster random sampling technique.This study uses an experimental method with a $2 \times 2$ factorial design quasi experimental design. The reasons for choosing a quasiexperimental design are: 1) classes that are carried out by using quantum larning learning strategies and expository learning strategies; and 2) the characteristics of students controlled only one aspect, namely musical intelligence.

Learning by using quantum learning strategies and expository learning strategies as independent variables, musical intelligence as a moderator variable and the acquisition of solfegio learning outcomes as dependent variables. These variables will then be included in the research design as shown in the following table:

TABLE 2. RESEARCH DESIGN

\begin{tabular}{|c|c|c|}
\hline \multicolumn{1}{|c|}{$\begin{array}{l}\text { Learning } \\
\text { Strategy } \\
\text { Musical } \\
\text { Intelligence }\end{array}$} & $\begin{array}{c}\text { Quantum } \\
\text { Learning (B1) }\end{array}$ & Expository (B2) \\
\hline Tinggi (A1) & A1B1 & A1B2 \\
\hline Rendah (A2) & A2B1 & A2B2 \\
\hline
\end{tabular}

To get a belief that the research design used is good enough in order to test the research hypothesis and the results obtained can be generalized to the study population, it is necessary to control the internal validity and external validity of the design (Ary, D. Jacobs, L. C. Razavieh, A. 1982)

The procedure of this research is a quasi-experimental study that compares two learning strategies namely quantum learning strategies and expository learning strategies and two subject classes, namely students who have high musical intelligence and students who have low musical intelligence.

This research is a quasi-experimental study involving two independent variables, one dependent variable, one moderator variable, namely: The dependent variable is the variable that is influenced by the independent variable. The dependent variable in this study is the learning outcomes of solfegio in arts and culture subjects. The independent variable is a variable that affects the dependent variable. There are two independent variables in this study, namely 1) learning strategies, namely quantum learning learning strategies and expository learning strategies as the first independent variable, 2) musical intelligence, which is divided into two groups: high musical intelligence and low musical intelligence as the second independent variable.

In this study two types of data collection tools were used, namely observation sheets to capture learning outcomes of solfegio practices and musicality tests to collect data about students' musical intelligence. The data collected in this study is data that is captured by using observation sheets for learning outcomes of solfegio and musicality tests to determine students' musical intelligence. In this study a talent / musical test or apptitude test was used to measure students' musical intelligence. This musical intelligence is measured by aspects of the Gordon PMMA (Primary Masures of Music Audiation) which are tonal and rhythmic, each of which can be developed through the introduction of tone, melody, harmony, tempo, and rhythm where respondents are instructed to answer or respond to commands and rated.

Before the actual research carried out by using the research instruments that have been compiled, a trial is first carried out. The purpose of the trial implementation is to find out how far the tool is able to measure what should be measured (validity) and how far a measuring device is reliable (reliable) and reliable. Descriptive statistics were used to describe the data and to test the proposed research hypothesis two-way ANOVA analysis was used. In this case the use of variance analysis, after the first requirement test is normality test using the Liliefors test ( $\mathrm{Lo}<\mathrm{Lt}$ ) at a significant level of 5\% with the condition that if it turns out Lo ${ }^{<} \mathrm{Lt}$ then the data tested is normally distributed. Furthermore, to test variance homogeneity is done using the Bartlett test $X_{h}^{2}<X_{t}^{2}$ ) at a significant level of 5\%. With the provision if it turns out that $X_{h}^{2<} X_{t}^{2}$ then the data is declared homogeneous (Sudjana, N. 2005).

The statistical hypothesis tested in this study includes:

1) $\mathrm{H}_{\mathrm{o}}: \mu \mathrm{A} 1=\mu \mathrm{A} 2$

$\mathrm{H}_{\mathrm{a}}: \mu \mathrm{A} 1 \quad \dot{\mathrm{C}} \mu \mathrm{A} 2$

2) $\mathrm{H}_{\mathrm{o}}: \mu \mathrm{B} 1=\mu \mathrm{B} 2$

$\mathrm{H}_{\mathrm{a}}: \mu \mathrm{B} 1 \quad$ i $\mu \mathrm{B} 2$

3) $\mathrm{H}_{0}: \mu \mathrm{SP} \times \mu \mathrm{KM}=0$

$\mathrm{H}_{\mathrm{a}}: \mu \mathrm{SP} \quad \times \mu \mathrm{KM} \neq 0$

\section{RESULT AND DISCUSSION}

The data that has been collected through research is tabulated according to the needs of data analysis listed in the research design which aims to show a general picture of the distribution or distribution of data. This study is a quasiexperimental study with a $2 \times 2$ factorial analysis design. To see the form of interaction between Learning Strategies and Musical Intelligence in influencing the learning outcomes of Solfegio, further testing was carried out using the Scheffe Test. A summary of the Scheffe Test can be seen in the table below. 
TABLE 3 Summary of Scheffe Test Results

\begin{tabular}{|c|c|c|c|c|c|}
\hline \multirow{2}{*}{ No } & \multicolumn{2}{|c|}{ Interaction } & $\mathrm{F}_{\mathrm{H}}$ & $\mathrm{F}_{\mathrm{T}}$ & \multirow{2}{*}{ Information } \\
\cline { 5 - 5 } & \multicolumn{2}{|c|}{$\begin{array}{c}\alpha= \\
0,05\end{array}$} & \\
\hline 1 & $\begin{array}{c}\mu \mathrm{A}_{1} \\
\mathrm{~B}_{1}\end{array}$ & $\begin{array}{c}\mu \mathrm{A}_{2} \\
\mathrm{~B}_{1}\end{array}$ & 33,75 & 3,99 & Significant \\
\hline 2 & $\begin{array}{c}\mu \mathrm{A}_{1} \\
\mathrm{~B}_{2}\end{array}$ & $\begin{array}{c}\mu \mathrm{A}_{2} \\
\mathrm{~B}_{2}\end{array}$ & 0,01 & 3,99 & Not significant \\
\hline 3 & $\begin{array}{c}\mu \mathrm{A}_{1} \\
\mathrm{~B}_{1}\end{array}$ & $\begin{array}{c}\mu \mathrm{A}_{1} \\
\mathrm{~B}_{2}\end{array}$ & 27,27 & 3,99 & Significant \\
\hline 4 & $\begin{array}{c}\mu \mathrm{A}_{2} \\
\mathrm{~B}_{1}\end{array}$ & $\begin{array}{c}\mu \mathrm{A}_{2} \\
\mathrm{~B}_{2}\end{array}$ & 0,43 & 3,99 & Not significant \\
\hline
\end{tabular}

Acceptance criteria if: F Calculate $>$ FTabel is tested significantly. Based on the results of the Scheffe test in Table 4.17 above it can be seen that four pairs of statistical hypotheses, namely:

From the results of calculations with the Scheffe test in Table 4.17 above, the results of data calculation is obtained where Fcount $=33.75$ while the critical value of Ftable is 3.99 thus Fcount $=33.75>$ Ftable 3.99, so the Zero Hypothesis $(\mathrm{Ho})$ is rejected. Thus, the research hypothesis states that the learning outcomes of Solfegio students who have high Musical Intelligence and are taught with a Quantum Learning Learning Strategy is higher than students who have a high Musical Intelligence and are taught with Expository Learning Strategies.

From the results of calculations with the Scheffe test in Table 4.17 above, the results of the calculation of the data obtained where Fcount $=0.01<$ Ftable is 3.99 , so that Ho is received. Thus, the research hypothesis states that the learning outcomes of Solfegio students who have low Musical Intelligence and are taught by using Quantum Learning Learning Strategies are higher than students who have low Musical Intelligence and are taught with the Expository Learning Strategy is untested.

From the results of calculations using the Scheffe test in Table 4.17 above, the results of data calculation are obtained where Fcount $=27.27>$ Ftable 3.99, so that the Zero Hypothesis (Ho) is rejected. Thus, the research hypothesis states that the learning outcomes of Solfegio students who have high Musical Intelligence and are taught by using Quantum Learning Learning Strategies are higher than students who have low musical intelligence and are taught with Quantum Learning Learning Strategies tested the truth.

From the results of calculations with the Scheffe test in Table 4.17 above, the results of data calculation are obtained where Fcount $=0.43<$ Ftable is 3.99 , thus accepting Ho. Thus, the research hypothesis states that the learning outcomes of Solfegio students who have high Musical Intelligence and are taught by using Expository Learning Strategies are higher than students who have low Musical Intelligence and are taught with Expository Learning Strategies.
Quantum Learning Learning Strategy is a fun learning process. Quantum Learning Learning Strategy is a learning knowledge and methodology that creates an effective learning environment, designing curriculum, delivering learning content and strategies to facilitate a successful and effective teaching and learning process. Learning Strategies Quantum learning seeks to transform a monotonous and boring learning atmosphere into a lively and joyful learning atmosphere by combining students' physical, psychological, and emotional potential into an integral unity of strength.

While the Expository Learning Strategy is classical teaching which tends to focus on the role of the teacher as a source of information. Killen, R (1998) named this Expository Learning Strategy with the term Direct Learning Strategy (direct insruction) because in this strategy the subject matter was directly delivered by the teacher, students were not required to find the material.

Based on the data obtained, shows that the average learning outcomes for students who are taught with Quantum Learning Learning Strategy $(=21.50)$ is better than the learning outcomes of students who are taught using the Expository Learning Strategy $(=18.94)$. From the results of the average comparison obtained, it can be concluded that student learning outcomes that are taught with Quantum Learning Learning Strategies are better than the learning outcomes of students who are taught using Expository Learning Strategies.

The findings of the study show that there is an interaction between the application of learning strategies with Musical Intelligence to the learning outcomes of Solfegio. Students who have high musical intelligence who are taught with the Quantum Learning Learning Strategy obtain higher learning outcomes from Solfegio than students who have high musical intelligence but are taught with an expository learning strategy.

\section{CONCLUSION}

Solfegio students' learning outcomes that were taught with Quantum Learning Learning Strategies were higher than those of Solfegio students who were taught with Expository Learning Strategies. The learning outcomes of Solfegio students who have high Musical Intelligence are higher than the learning outcomes of Solfegio students who have low Musical Intelligence. There is an interaction between Learning Strategies and Musical Intelligence on learning outcomes of Solfegio students who have high Musical Intelligence higher learning outcomes if they are taught with Quantum Learning Learning Strategies while students who have low Musical Intelligence are higher learning outcomes if they are taught with Expository Learning Strategies.

\section{REFERENCES}

[1] Ary, D. Jacobs, L. C. Razavieh, A. 1982. PengantarPenelitian Dalam Pendidikan. (penerjemah: Furchan, A). Surabaya: Usaha Nasional.

[2] DePorter, B \& Hernacki, M. 2006.Quantum Learning: Membiasakan Belajar Nyaman dan Menyenangkan . Bandung: PT. Mizah Pustaka 
[3] Gardner, H. 1983. Multiple Intelligences (Kecerdasan Majemuk), Batam:Interaksara

[4] Killen, R. 1998. Efektif Teaching Strategies. Australia: Social Science Press

[5] Sudjana, N. 2005. Penilaian Hasil Proses Belajar Mengajar. Bandung: Remaja Rosdakarya. 